\title{
OCCURRENCE OF BIFLAVONES IN LEAVES OF Caesalpinia pyramidalis SPECIMENS
}

Marcus V. Bahia

Centro de Formação de Professores, Universidade Federal do Recôncavo da Bahia, 45300-000 Amargosa - BA, Brasil

Juceni P. David

Faculdade de Farmácia, Universidade Federal da Bahia, 40170-290 Salvador - BA, Brasil

Jorge M. David*

Instituto de Química, Universidade Federal da Bahia, 40170-290 Salvador - BA, Brasil

Recebido em 17/9/09; aceito em 2/2/10; publicado na web em 18/6/10

\begin{abstract}
The chloroform partition of methanol extract of leaves of Caesalpinia pyramidalis was submitted to different chromatographic procedures which afforded besides agathisflavone and taxifolin, the minor biflavones loniflavone, amentoflavone, 5'hydroxyamentoflavone and podocarpusflavone A. The structures of the compounds were established on the basis of NMR and MS data analysis. Besides, the content of biflavones of different specimens of $C$. pyramidalis, which are collected in different habitats of the Brazilian semi-arid region, was determinated by LC-APCI-MS analysis. These analysis demonstrated that only the specimens harvested in Bahia state showed collectively the presence of agathisflavone, amentoflavone, sequoiaflavone and podocarpusflavone A.
\end{abstract}

Keywords: Caesalpinia pyramidalis; biflavones; flavonoid analysis.

\section{INTRODUCTION}

Caesalpinia pyramidalis Tul. is a tree belonging to the family Leguminosae-Caesalpinoideae, which is endemic of Brazilian northeastern, especially in the caatinga. It is popularly known as "catingueira" or "pau-de-rato" and its leaves are used in the preparation of infusions and decocts, which are used by the local population as diuretic, antidispeptic, stomach aches and for fever. ${ }^{1}$

Species of this genus are known to present different biological activities. For instance, the extract of seeds of $C$. bonducella showed antimicrobial activities ${ }^{2}$ and they are also employed in the treatment of diabetes. ${ }^{3}$ Extracts of $C$. volkensii and C. pluviosa presents antimalarial activity ${ }^{4}$ and $C$. pulcherrima antiviral activity. ${ }^{5}$ The extract of $C$. pyramidalis is responsible for antibacterial, ${ }^{6}$ larvicidal and moluscicidal ${ }^{7}$ activities.

The presence of diterpenes and flavonoids besides other phenolics is characteristic of this genus as well as the subfamily. ${ }^{8}$ From the previous studies regarding with $C$. pyramidalis were isolated phenylpropanoids, biflavonoids, lignan, flavonoids besides gallic acid. ${ }^{9}$

In the present study it was reported the isolation and characterization of the minor biflavonoids loniflavone (1), amentoflavone (2), 5 -hydroxyamentoflavone (3) and podocarpusflavone A (5), besides agathisflavone (4) and taxifolin (6) from the leaves of $C$. pyramidalis (Figure 1). It was also evaluated by LC-MS the composition of biflavonoids present in leaves of specimens of $C$. pyramidalis collected in different habitats of Brazilian semi-arid region.

\section{EXPERIMENTAL}

\section{General procedures}

The NMR spectra were obtained in Varian Gemini 2000, Inova 500 and Bruker AMX500 spectrometers operating at 300 and 500 $\mathrm{MHz}\left({ }^{1} \mathrm{H}\right)$ and, 75 and $125 \mathrm{MHz}\left({ }^{13} \mathrm{C}\right)$, employing $\mathrm{CD}_{3} \mathrm{OD}, \mathrm{C}_{5} \mathrm{D}_{5} \mathrm{~N}$ and $\left(\mathrm{CD}_{3}\right)_{2} \mathrm{CO}$ as solvents and TMS as internal standard. The MS and the LC-MS analysis were carried out in a Shimadzu chromatographer mod.

*e-mail: jmdavid@ufba.br<smiles>O=c1cc(-c2ccc(Oc3ccc(-c4cc(=O)c5c(O)cc(O)cc5o4)cc3O)cc2)oc2cc(O)cc(O)c12</smiles><smiles>[R]c1cc(-c2cc(=O)c3c(O)cc(O)cc3o2)cc(-c2c(O)cc(O)c3c(=O)cc(-c4ccc(O)cc4)oc23)c1O</smiles><smiles>O=C1c2c(O)cc(O)cc2O[C@H](c2ccc(O)c(O)c2)C1O</smiles><smiles>[R20]c1ccc(-c2cc(=O)c3c(O)cc(O)c(-c4cc(-c5cc(=O)c6c(O)cc([R20])cc6o5)ccc4O)c3o2)cc1</smiles>

$5 \mathrm{R}_{1}=\mathrm{H} ; \mathrm{R}_{2}=\mathrm{CH}_{3}$ $8 \mathrm{R}_{1}=\mathrm{CH}_{3} ; \mathrm{R}_{2}=\mathrm{H}$ 
Table 1. Biflavonoid variation (\%) found in diverse specimens of $C$. pyramidalis

\begin{tabular}{lllll}
\hline Specimen & Agathisflavone & Amentoflavone & Sequoiaflavone & Podocarpusflavone A \\
\hline Feira de Santana* & 0.5 & - & - & - \\
Feira de Santana* (tree age: 14 years old) & 0.05 & - & - & - \\
Feira de Santana*"(tree age: 10 years old) & 0.001 & - & - & - \\
Ipirá* & 0.01 & - & - & - \\
Riachão do Jacuípe* $_{\text {Valente* }}^{*}$ & - & 0.03 & 0.001 & - \\
Serra Talhada** & 1.0 & 0.001 & - & - \\
Sertânia** & - & - & - & - \\
Santa Luzia*** & - & - & & - \\
\hline
\end{tabular}

"Bahia State, ${ }^{* *}$ Pernambuco State, , Paraíba State

LCMS-2310, with autosampler $5 \mu \mathrm{L}$ loop. The detection of biflavonoids was obtained in positive and negative APCI mode. The chromatograms were obtained using a VP-ODS (RP18 - $5 \mu \mathrm{m}$; 3.9 x $150 \mathrm{~mm}$ ) column and as mobile phase the isocratic system of $\mathrm{MeOH}: \mathrm{H}_{2} \mathrm{O}(75: 25)$, with flow rate of $0.2 \mathrm{~mL} \mathrm{~min}^{-1}$. The pure biflavonoids used as standards were kindly provided by Prof. M. G. de Carvalho (UFRRJ). In the conventional chromatographic methods were used for CC silica gel $60(63-200 \mu \mathrm{m})$ and Sephadex LH-20 and, it was used silica gel TLC plates to monitor the chromatographic fractions which were revealed employing iodine fumes and UV light (254/366 nm).

\section{Plant material}

Botanical material of Caesalpinia pyramidalis were collected in the surroundings of Valente (BA), Feira de Santana (BA), Riachão do Jacuípe (BA), Ipirá (BA), Serra Talhada (PE), Sertânia (PE) and Santa Luzia (PB). The specimens were identified by Prof. Dr. L. P. de Queiróz (Universidade Estadual de Feira de Santana) and Profa. Dra. M. de F. Agra (Laboratório de Tecnologia Farmacêutica UFPB). The vouchers were deposited at Herbário Alexandre Leal da Costa of Instituto de Biologia of Universidade Federal da Bahia under number 240291.

\section{Extraction and isolation}

The dried and grounded leaves $(680 \mathrm{~g})$ were submitted to extraction with $\mathrm{MeOH}$ for $48 \mathrm{~h}$. The methanolic extract was sequentially submitted to partition between hexane and $\mathrm{MeOH}: \mathrm{H}_{2} \mathrm{O}(9: 1)$ furnishing the hydroalchoolic and hexanic phases $(7.5 \mathrm{~g})$. In sequence, it was added $\mathrm{H}_{2} \mathrm{O}$ in the hydromethanolic solution in order to obtain a solution of $\mathrm{MeOH} / \mathrm{H}_{2} \mathrm{O}$ (6:4). Thus, this hydroalchoolic solution was submitted to a partition between $\mathrm{CHCl}_{3}$ furnishing the $\mathrm{CHCl}_{3}$ phase $(23.9 \mathrm{~g})$.

The $\mathrm{CHCl}_{3}$ phase was submitted to a silica gel $\mathrm{CC}$ using mixtures of $\mathrm{CHCl}_{3}$ :EtOAc in increasing polarities. The fractions eluted with $\mathrm{CHCl}_{3}$ :EtOAc (6:4) were grouped (936.4 mg) after TLC analysis and submitted to a Sephadex LH-20 CC using a mixture of $\mathrm{CH}_{2} \mathrm{Cl}_{2}$ : $\left(\mathrm{CH}_{3}\right)_{2} \mathrm{CO}(1: 4)$ with permitted to obtain enriched phenol fractions $(254.4 \mathrm{mg})$. This mixture was submitted to a silica gel 60 $\mathrm{CC}$ and eluted with $\mathrm{CHCl}_{3}: \mathrm{MeOH}$ (95:5 to 8:2) which permitted to obtain the compounds $\mathbf{1}$ (7.9 mg), 2 (6.3 mg), 3 (9.3 mg), 4 (100.0 $\mathrm{mg}), \mathbf{5}(15.5 \mathrm{mg})$ and $\mathbf{6}(9.5 \mathrm{mg})$.

\section{Determination of biflavonoids in specimens of $C$. pyramidalis}

The leaves of $C$. pyramidalis $(100 \mathrm{~g})$ collected in different places were submitted to extraction with hexane and $\mathrm{CHCl}_{3}$. The $\mathrm{CHCl}_{3}$ phase was submitted to $\mathrm{CC}$ over silica gel 60 and mixtures of $\mathrm{CHCl}_{3}$ :EtOAc (Table 1). The biflavonoid enriched fractions were eluted with $\mathrm{CHCl}_{3}$ : EtOAc (1:1). These fractions were submitted to a LC-MS analysis in order to determinate the content of biflavonoids.

Loniflavone (1). Amorphous yellow power. m. p. 242-244 ${ }^{\circ} \mathrm{C}$. MS (APCI) $m / z=537[\mathrm{M}-\mathrm{H}]^{-1} .{ }^{1} \mathrm{H}$ NMR [500 MHz, $\left.\left(\mathrm{CD}_{3}\right)_{2} \mathrm{CO}\right]$ : Unity I: $\delta 6.71(s, 1 \mathrm{H}, \mathrm{H}-3) ; \delta 12.92(s, 1 \mathrm{H}, \mathrm{H}-5) ; \delta 6.26(d, 1 \mathrm{H}, J$ $=2.0 \mathrm{~Hz}, \mathrm{H}-6) ; \delta 6.54(d, 1 \mathrm{H}, J=2.0 \mathrm{~Hz}, \mathrm{H}-8) ; \delta 8.06(d, 2 \mathrm{H}, J=$ $9.0 \mathrm{~Hz}, \mathrm{H}-2^{\prime} / \mathrm{H}^{-6}$ '); $\delta 7.14$ (d, 2H, $J=9.0$ and $2.0 \mathrm{~Hz}, \mathrm{H}-3^{\prime} / \mathrm{H}^{-5}$ '); Unity II: $\delta 6.70(s, 1 \mathrm{H}, \mathrm{H}-3) ; \delta 12.93(s, 1 \mathrm{H}, \mathrm{H}-5) ; \delta 6.27(d, 1 \mathrm{H}, J$ $=2.0 \mathrm{~Hz}, \mathrm{H}-6) ; \delta 6.55(d, 1 \mathrm{H}, J=2.0 \mathrm{~Hz}, \mathrm{H}-8) ; \delta 7.89(d, 1 \mathrm{H}, J=$ $\left.2.0 \mathrm{~Hz}, \mathrm{H}-2^{\prime}\right) ; \delta 7.28(d, 1 \mathrm{H}, J=8.0 \mathrm{~Hz}, \mathrm{H}-5$ '); $\delta 7.91(d d, 1 \mathrm{H}, J=$ 8.0 and $\left.2.0 \mathrm{~Hz}, \mathrm{H}-6^{\prime}\right)$.

Amentoflavone (2). Amorphous yellow power. m. p. 254-256 ${ }^{\circ} \mathrm{C}$. MS (APCI) $m / z=538 .{ }^{1} \mathrm{H}$ NMR $\left(300 \mathrm{MHz}, \mathrm{CD}_{3} \mathrm{OD}\right)$ : Unity I: $\delta 6.56(s, 1 \mathrm{H}, \mathrm{H}-3) ; \delta 6.22(s, 1 \mathrm{H}, \mathrm{H}-6) ; \delta 7.66(d, 2 \mathrm{H}, J=8.7 \mathrm{~Hz}$, H-2'/H-5'); $\delta 6.58$ (d, 2H, $\left.J=8.7 \mathrm{~Hz}, \mathrm{H}^{\prime} 3^{\prime} / \mathrm{H}^{\prime} 5^{\prime}\right)$; Unity II: $\delta 6.49$ $(s, 1 \mathrm{H}, \mathrm{H}-3) ; \delta 5.99(d, 1 \mathrm{H}, J=2.0 \mathrm{~Hz}, \mathrm{H}-6) ; \delta 6.05(d, 1 \mathrm{H}, J=$ $2.0 \mathrm{~Hz}, \mathrm{H}-8) ; \delta 8.26\left(d, 1 \mathrm{H}, J=2.3 \mathrm{~Hz}, \mathrm{H}-2^{\prime}\right) ; \delta 7.09(d, 1 \mathrm{H}, J=$ $\left.8.7 \mathrm{~Hz}, \mathrm{H}-5^{\prime}\right) ; \delta 7.88$ ( $d d, 1 \mathrm{H}, J=8.7$ and $2.3 \mathrm{~Hz}, \mathrm{H}-6$ '). ${ }^{13} \mathrm{C} \mathrm{NMR}$ (75 MHz, CD $30 D)$ : Unity I: $\delta 165.5(\mathrm{C}, \mathrm{C}-2) ; \delta 102.7(\mathrm{CH}, \mathrm{C}-3)$; $\delta 182.8(\mathrm{C}, \mathrm{C}-4) ; \delta 162.4(\mathrm{C}, \mathrm{C}-5) ; \delta 100.1(\mathrm{CH}, \mathrm{C}-6) ; \delta 164.2(\mathrm{C}$, $\mathrm{C}-7) ; \delta 103.8$ (C, C-8); $\delta 156.6$ (C, C-9); $\delta 108.5$ (C, C-10); $\delta 121.9$ (C, C-1'); $\delta 129.3\left(\mathrm{CH}, \mathrm{C}-2^{\prime} / \mathrm{C}-6^{\prime}\right) ; \delta 115.1\left(\mathrm{CH}, \mathrm{C}-3^{\prime} / \mathrm{C}-5^{\prime}\right) ; \delta 162.0$ (C, C-4'); Unity II: $\delta 165.6$ (C, C-2); $\delta 102.9(\mathrm{CH}, \mathrm{C}-3) ; \delta 183.8(\mathrm{C}$, C-4); $\delta 163.5$ (C, C-5); $\delta 99.9$ (CH, C-6); $\delta 163.5$ (C, C-7); $\delta 94.8$ (CH, C-8); $\delta 156.6$ (C, C-9); $\delta 108.5$ (C, C-10); $\delta 122.2$ (C, C-1'); $\delta 132.3\left(\mathrm{CH}, \mathrm{C}-2^{\prime}\right) ; 123.1\left(\mathrm{C}, \mathrm{C}-3^{\prime}\right) ; \delta 161.9\left(\mathrm{C}, \mathrm{C}-4{ }^{\prime}\right) ; \delta 117.4(\mathrm{CH}$, C-5'); $\delta 128.7$ (CH, C-6').

5'-Hydroxyamentoflavone (3). Amorphous yellow power. m. p. 288-290 ${ }^{\circ} \mathrm{C}$. MS (APCI) $\mathrm{m} / \mathrm{z}=554 .{ }^{1} \mathrm{H} \mathrm{NMR}\left(500 \mathrm{MHz}, \mathrm{C}_{5} \mathrm{D}_{5} \mathrm{~N}\right)$ : Unity $\mathrm{I}: \delta 6.94(s, 1 \mathrm{H}, \mathrm{H}-3) ; \delta 6.75(d, 1 \mathrm{H}, J=1.8 \mathrm{~Hz}, \mathrm{H}-6) ; \delta 6.84(d, 1 \mathrm{H}$, $J=1.8 \mathrm{~Hz}, \mathrm{H}-8) ; \delta 8.56\left(d, 1 \mathrm{H}, J=2.5 \mathrm{~Hz}, \mathrm{H}-2{ }^{\prime}\right) ; \delta 7.96(\mathrm{~d}, 1 \mathrm{H}, J$ $=2.5 \mathrm{~Hz}, \mathrm{H}-6$ ') ; Unity II: $\delta 6.93(s, 1 \mathrm{H}, \mathrm{H}-3) ; \delta 6.89(s, 1 \mathrm{H}, \mathrm{H}-6) ; \delta$ 7.89 ( $d, 2 \mathrm{H}, J=8.5 \mathrm{~Hz}, \mathrm{H} 2$ '/H6'); $\delta 7.47$ ( $d, 2 \mathrm{H}, J=8.5 \mathrm{~Hz}, \mathrm{H} 3^{\prime} / \mathrm{H}^{\prime}$ ').

Taxifolin (6). Yellow cristals. m. p. $242{ }^{\circ} \mathrm{C} .{ }^{1} \mathrm{H}$ NMR $(500 \mathrm{MHz}$, $\left.\mathrm{CD}_{3} \mathrm{OD}\right): \delta 4.92(d, 1 \mathrm{H}, J=11.0 \mathrm{~Hz}, \mathrm{H}-2) ; \delta 4.50(d, 1 \mathrm{H}, J=11.0$ $\mathrm{Hz}, \mathrm{H}-3) ; \delta 5.91(d, 1 \mathrm{H}, J=2.0 \mathrm{~Hz}, \mathrm{H}-6) ; \delta 5.89(d, 1 \mathrm{H}, J=2.0 \mathrm{~Hz}$, $\mathrm{H}-8) ; \delta 6.86\left(d d, 1 \mathrm{H}, J=2.0\right.$ and $\left.8.0 \mathrm{~Hz}, \mathrm{H}-6{ }^{\prime}\right) ; \delta 6.81(d, 1 \mathrm{H}, J=$ $\left.8.0 \mathrm{~Hz}, \mathrm{H}-5^{\prime}\right) ; \delta 6.97\left(d, 1 \mathrm{H}, J=2.0 \mathrm{~Hz}, \mathrm{H}-2^{\prime}\right)$. RMN ${ }^{13} \mathrm{C}(75 \mathrm{MHz}$, CD 3 OD): $\delta 85.09$ (CH, C-2); $\delta 73.64$ (CH, C-3); $\delta 198.37$ (C, C-4); $\delta$ 164.27 (C, C-5); $\delta 97.29$ (CH, C-6); $\delta 168.72$ (C, C-7); $\delta 96.27$ (CH, $\mathrm{C}-8) ; \delta 164.47$ (C, C-9); $\delta 101.79$ (C, C-10); $\delta 129.82$ (C, C-1'); $\delta$ $115.85\left(\mathrm{CH}, \mathrm{C}-2^{\prime}\right) ; \delta 116.05\left(\mathrm{CH}, \mathrm{C}-5^{\prime}\right) ; \delta 147.11\left(\mathrm{C}, \mathrm{C}-4^{\prime}\right) ; \delta 146.28$ $\left(\mathrm{C}, \mathrm{C}-3^{\prime}\right) ; \delta 120.88\left(\mathrm{CH}, \mathrm{C}-6^{\prime}\right)$.

\section{RESULTS AND DISCUSSION}

The structure of compound 1 was elucidated by MS and NMR data analysis. The pseudo-molecular ion observed at $\mathrm{m} / z, 537$ [M-H] 
recorded in negative MS-APCI mode together with ${ }^{1} \mathrm{H}$ and ${ }^{13} \mathrm{C}$ NMR data, including DEPT, permitted to propose the molecular formula $\mathrm{C}_{30} \mathrm{H}_{18} \mathrm{O}_{10}$ and consequently determinate the biflavonoid nature of compound 1. It was observed two singlets at $\delta 12.93$ and 12.92 in the ${ }^{1} \mathrm{H}$ NMR spectra, whose disappeared in presence of $\mathrm{D}_{2} \mathrm{O}$, they were indicative of presence of two flavonoid units bearing hydroxyl groups at the $\mathrm{C}-5$ with hydrogens bonding at carbonyl groups $(\mathrm{C}-4)$. The presence of two other singlets $(\delta 6.71$ and 6.70) in the same spectra was characteristic of $\mathrm{H}-3$ of flavones. It was also possible to verify the presence of a 1,4-disubstitued B ring for one unity (I) due the doublets observed at $\delta 8.06$ and $7.14(J=9.0$ and $2.0 \mathrm{~Hz})$. For the other B ring unity (II) the spectra showed peaks of an AMX system at $\delta 7.91(J=8$ and $2 \mathrm{~Hz}), 7.89(J=2 \mathrm{~Hz})$ and $7.28(J=8 \mathrm{~Hz})$. The presence of four doublets for A ring $(J=2 \mathrm{~Hz}$ each) indicated the linkages between the two unities of flavones were not placed in these rings. The ${ }^{13} \mathrm{C}$ NMR spectra data (Experimental Section) and the ${ }^{1} \mathrm{H}-{ }^{1} \mathrm{H}$ gCOSY showed hydrogen coupling systems and corroborated compound 1 was a biflavone.

The analysis of the HSQC spectra of $\mathbf{1}$ permitted to verify correlations which were important to distinguish the carbons and the respective hydrogens. So, this spectra was important in the identification of the aromatic carbons of 1,4-dissubstitued system of B ring of Unity I. In the same way it contributed to recognize the resonances of aromatic carbons of B ring of Unity II.

Comparison of NMR data (Table 2) of compound 1 with loniflavone and ochnaflavone ${ }^{10}(7)$ was important to propose that the linkage between both units occurred by B rings. The HMBC correlations indicated 1 was a C-4'-O-C-4' biflavone through the observed correlations of H-6' ( $\delta 7.91)$ and C-4' ( $\delta$ 142.8), H-2'/H-5' and C-3' and C-4' (Figure 2). These findings permitted to identify $\mathbf{1}$ as being loniflavone. This is the second occurrence of this biflavone, it was previously isolated in Lonicera japonica (Caprifoliaceae). ${ }^{11}$

Table 2. ${ }^{13} \mathrm{C}$ NMR data of $\mathbf{1}$, loniflavone and ochnaflavone [125 MHz, $\left.\left(\mathrm{D}_{3} \mathrm{C}\right)_{2} \mathrm{CO}, \delta(\mathrm{ppm})\right]$

\begin{tabular}{|c|c|c|c|}
\hline $\mathrm{C}$ & & $\delta^{13} \mathrm{C}$ & \\
\hline Unity I/Unity II & 1 & Loniflavone $^{11}$ & Ochnaflavone $e^{10}$ \\
\hline $2 / 2$ & $163.63 / 162.98$ & $163.4 / 163.1$ & $163.1 / 163.5$ \\
\hline $3 / 3$ & $104.80 / 104.49$ & $105.0 / 104.8$ & $105.1 / 104.8$ \\
\hline $4 / 4$ & $182.71 / 182.68$ & $182.5 / 182.5$ & $183.1 / 182.9$ \\
\hline $5 / 5$ & $161.61 / 161.61$ & $161.1 / 161.1$ & $163.4 / 103.2$ \\
\hline $6 / 6$ & $99.50 / 99.50$ & $99.9 / 99.9$ & $99.9 / 96.9$ \\
\hline $7 / 7$ & $164.77 / 164.72$ & $166.1 / 166.1$ & $165.0 / 167.4$ \\
\hline $8 / 8$ & $94.51 / 94.49$ & $94.7 / 94.7$ & $94.8 / 95.9$ \\
\hline $9 / 9$ & $158.46 / 158.40$ & $157.4 / 157.4$ & $158.8 / 166.3$ \\
\hline $10 / 10$ & $104.99 / 105.03$ & $105.0 / 104.7$ & $105.4 / 103.2$ \\
\hline $1^{\prime} / 1{ }^{\prime}$ & $125.84 / 124.09$ & $125.8 / 125.1$ & $126.0 / 132.3$ \\
\hline $2^{\prime} / 2^{\prime}$ & $128.85 / 121.35$ & $125.8 / 121.4$ & $129.1 / 121.5$ \\
\hline $3^{\prime} / 3^{\prime}$ & $117.09 / 153.62$ & $116.5 / 154.7$ & $117.5 / 142.8$ \\
\hline 4'/4' & $161.61 / 142.85$ & $161.0 / 144.4$ & $162.1 / 150.5$ \\
\hline $5 ' / 5$ & $117.09 / 118.63$ & $116.5 / 118.8$ & $117.5 / 118.4$ \\
\hline $6^{\prime} / 6^{\prime}$ & $128.85 / 125.56$ & $128.4 / 124.8$ & $129.1 / 125.5$ \\
\hline
\end{tabular}

Compound 3 was identified by MS and NMR data analysis and comparison with literature. The molecular ion observed at $\mathrm{m} / \mathrm{z} 554$ in the APCI-MS together with ${ }^{1} \mathrm{H}$ and ${ }^{13} \mathrm{C}$ NMR data permitted to propose the molecular formula $\mathrm{C}_{30} \mathrm{H}_{18} \mathrm{O}_{11}$ and determinate $\mathbf{3}$ was a biflavonoid. This compound was identify as 5 '-hydroxyamentoflavone by comparison with amentoflavone ${ }^{12}$ spectral data and with previously data published to this compound. This compound was formerly isolated from Bartramia ithyphylla (Bartramiaceae) $)^{13}$ and<smiles>O=c1cc(-c2ccc(Oc3ccc(-c4cc(=O)c5c(O)cc(O)cc5o4)cc3)cc2)oc2cc(O)cc(O)c12</smiles><smiles>O=c1cc(-c2ccc(Oc3ccc(-c4cc(=O)c5c(O)cc(O)cc5o4)cc3)cc2)oc2cc(O)cc(O)c12</smiles>

Figure 2. Key correlations observed in the HMBC of 1 and structure of compound 7

Rhytidiadelphus squarrosus (Hylocomiaceae) ${ }^{14}$ but it is the first occurrence in Leguminosae.

Amentoflavone (2), agathisflavone (4), podocarpusflavone A (5) and taxifolin $(\mathbf{6})^{15}$ were identify by spectrometric data analysis and direct comparison with literature.

Since, in previous studies with leaves of $C$. pyramidalis it was isolated agathisflavone and other minor biflavonoids, it was developed a method to determinate the content of these compounds in different specimens of $C$. pyramidalis whose were collected in diverse neighborhoods of Brazilian "caatinga" region. For determination of the biflavones was utilized LC-APCI-MS analysis employing detection in negative mode and, agathisflavone, amentoflavone, sequoiaflavone $(\mathbf{8})^{16}$ and podocarpusflavone A were used as standards. So, the $\mathrm{CHCl}_{3}$ extracts of leaves of different specimens of C. pyramidalis were submitted to a CC and the phenolic enriched fractions were injected in the HPLC. Table 1 summarizes the results obtained in these analysis in percentage relation of $\mathrm{CHCl}_{3}$ extracts. In the samples harvested in Santa Luzia-PB, Serra Talhada-PE and Sertânia-PE was not detected the presence of any biflavones in the fractions. In all the specimens collected in Bahia State it was detected the occurrence of these compounds. However in some of them the presence of minor biflavonoids was widely changed. Nevertheless in all samples agathisflavone (4) was the biflavonoid present in major concentration (0.01-1\%) and in one specimen (Riachão do Jacuípe) it was not detected. These preliminary findings indicate the occurrence of biflavonoids in $C$. pyramidalis can be dependent of habitat (e.g climate, soil composition), physical characteristics (age of tree) or botanical variations. Beside this, the presence of biflavonoids in Leguminosae is still rare. They are restricted only in selected species such as Ormocarpum kirkii, ${ }^{17}$ Diphysa robinioides, ${ }^{18}$ Lupinus albus ${ }^{19}$ and Dioclea lasiophylla. ${ }^{20}$ This is the first occurrence of 1, 2, 5 and $\mathbf{6}$ in the Leguminosae family.

\section{SUPPLEMENTARY MATERIAL}

Supplementary information as chromatograms of fractions of different specimes of $C$. pyramidalis and NMR spectra of biflavonoids are available free of charge as PDF file at http://quimicanova. sbq.org.br.

\section{ACKNOWLEDGMENTS}

The authors are grateful to Conselho Nacional de Desenvolvimento Científico e Tecnológico - CNPq (Brasil), IMSEAR (CNPq/ MCT), FAPESB and Fundação Coordenação de Aperfeiçoamento de Pessoal de Nível Superior (CAPES) for fellowship support and grants. 


\section{REFERENCES}

1. Bahia, SEPLANTEC - Subsecretária de Ciência e Tecnologia; Inventário de Plantas Medicinais do Estado da Bahia, Salvador, 1979.

2. Saeed, M. A.; Sabi, R. A. W.; Fitoterapia 2001, 72, 807; Aqil, F.; Ahmad, I.; J. Microbiol. Biotechnol. 2003, 19, 653.

3. Chakrabarti, S.; Biswas, T. K.; Seal, T.; Rokeya, B.; Ali, L.; Khan, A. K. A.; Nahar, N.; Mosihuzzaman, M.; Mukherjee, B.; J. Ethnopharmacol. 2005, 97, 117; Biswas, T. K.; Bandyopadhyay, S.; Mukherjee, B.; Muklerjee, B.; Sengupta, B. R.; Int. J. Ethnopharmacol. 1997, 35, 261; Grover, J. K.; Vats, V.; Yadav, S.; J. Ethnopharmacol. 2002, 81, 81; Sharma, S. R.; Dwivedi, S. K.; Swarup, D.; J. Ethnopharmacol. 1997, 58, 39.

4. Kuria, K. A. M.; De Coster, S.; Muriuki, G.; Masengo, W.; Kibwage, I.; Hoogmartens, J.; Laekman, G. M.; J. Ethnopharmacol. 2001, 74, 141; Deharo, E.; Bourdy, G.; Quenevo, C.; Munoz, V.; Sauvain, M. A.; J. Ethnopharmacol. 2001, 77, 91.

5. Alanis, A. D.; Calzada, F.; Cervantes, J. A.; Torres, J.; Ceballos, G. M.; J. Ethnopharmacol. 2005, 100, 153.

6. Sant'ana, A. E. G.; Luna, J. S.; Santos, A. F.; Lima, M. R. F.; Andrade, M. C. C.; Genet, J. P.; Márquez, B.; Neuville, L.; Moreau, N.; J. Ethnopharmacol. 2006, 105, 137.

7. Sant'ana, A. E. G.; Luna, J. S.; Santos, A. F.; Lima, M. R. F.; Omena, M. C.; Mendonça, F. A. C.; Bieber, L. W.; J. Ethnopharmacol. 2005, 97, 199.

8. Mors, W. B.; Nascimento, M. C.; Pereira, B. M. R.; Pereira, N. A.; Phytochemistry 2000, 55, 627; David, J. M.; David, J. P.; Ferrari, J.; Guimarães, A. G.; Lima, F. W. M.; Souza, G. L. S.; J. Braz. Chem. Soc. 2007, 18, 1585; Correia Júnior, C. A. B.; Santos, M. V.; David, J. M.; David, J. P.; Magalhães, P. J. C.; Lahlou, S.; Vasc. Pharmacol. 2007, 46, 60; Lima, L. S.; Lima, M. V. B.; David, J. P.; Giulietti, A. M.; de Queiróz, L. P.; David, J. M.; J. Braz. Chem. Soc. 2009, 20, 1921; David, J. P.; David, J. M.; Yang, S.; Cordell, G. A.; Phytochemistry 1999, 50, 443.
9. Bahia, M. V.; Mendes, C. C.; David, J. M.; David, J. P.; Fitoterapia 2000, 71, 205; Bahia, M. V.; Dos Santos, J. B.; David, J. P.; David, J. M.; J. Braz. Chem. Soc. 2005, 16, 1402.

10. Rao, K. V.; Sreeramulu, K.; Rao, C. V.; Gunasekar, D.; J. Nat. Prod. 1997, 60, 632.

11. Kumar, N.; Singh, B.; Bhandari, P.; Gupta, A. P.; Uniyal, S. K.; Kaul, V. K.; Phytochemistry 2005, 66, 2740.

12. Chari, V. M.; Ilyas, M.; Wagner, H.; Neszmelyi, A.; Chen, F. C.; Chen, L. K.; Lin, Y. C.; Lin, Y. M.; Phytochemistry 1977, 16, 1273.

13. López-Saez, J. A.; Pérez, J. A.; Negueruela, A. V.; Z. Naturforsch., C: J. Biosci. 1995, 50, 311.

14. Brinkmeier, E.; Geiger, H.; Zinsmeister, H. D.; Phytochemistry 1999, 52, 297.

15. Arriaga, A. M. C.; Castro, M. A. B.; Silveira, E. R.; Braz-Filho, R.; J. Braz. Chem. Soc. 2000, 11, 187.

16. Hameed, N.; Ilyas, M.; Rahman, W.; Okigawa, M.; Kawano, N.; Phytochemistry 1973, 12, 1494.

17. Nyandat, E.; Hassanali, A.; De Vicente, Y.; Multari, G.; Galeffi, C.; Phytochemistry 1990, 29, 2361.

18. Castro, O.; Valverde, V.; Phytochemistry 1985, 24, 367.

19. Sakasai, M.; Fukui, H.; Kyaw, A. N.; Tahara, S.; Z. Naturforsch., C: J. Biosci. 2000, 55, 165.

20. Barreiros, A. L. B. S.; David, J. P.; de Queiróz, L. P.; David, J. M.; Phytochemistry 2000, 55, 805. 


\section{OCCURRENCE OF BIFLAVONES IN LEAVES OF Caesalpinia pyramidalis SPECIMENS}

Marcus V. Bahia

Centro de Formação de Professores, Universidade Federal do Recôncavo da Bahia, 45300-000 Amargosa - BA, Brasil Juceni P. David

Faculdade de Farmácia, Universidade Federal da Bahia, 40170-290 Salvador - BA, Brasil

Jorge M. David*

Instituto de Química, Universidade Federal da Bahia, 40170-290 Salvador - BA, Brasil
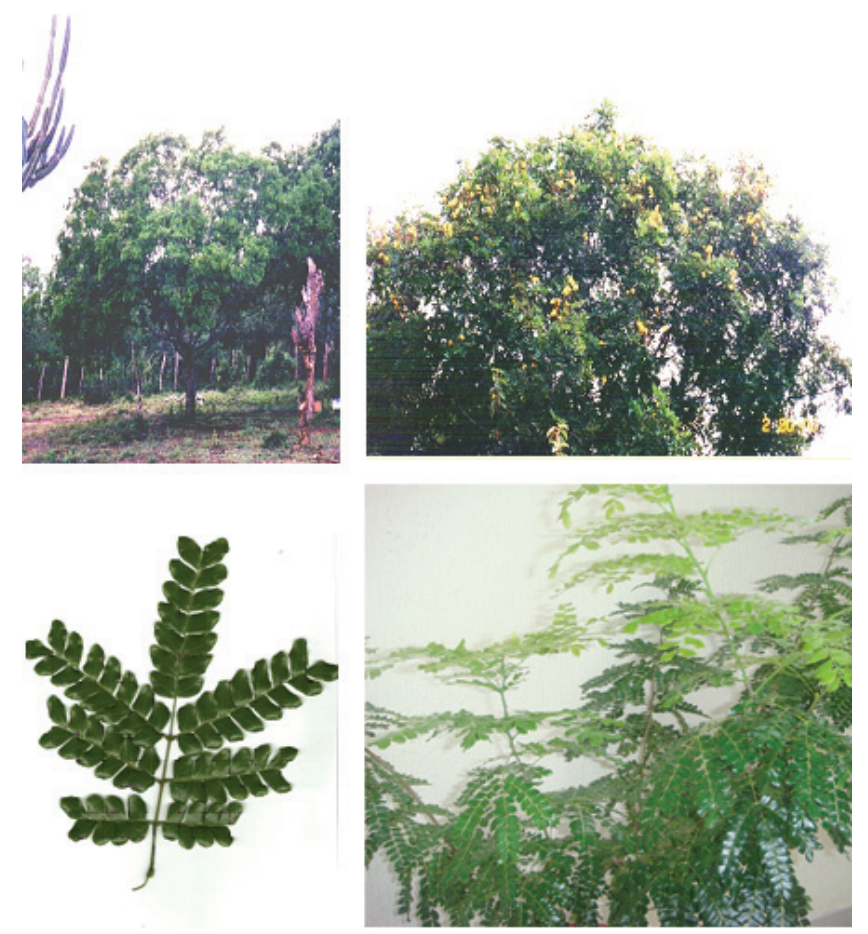

Figure 1S. Especimens of Caesalpinia pyramidalis (photos by J. M. David)

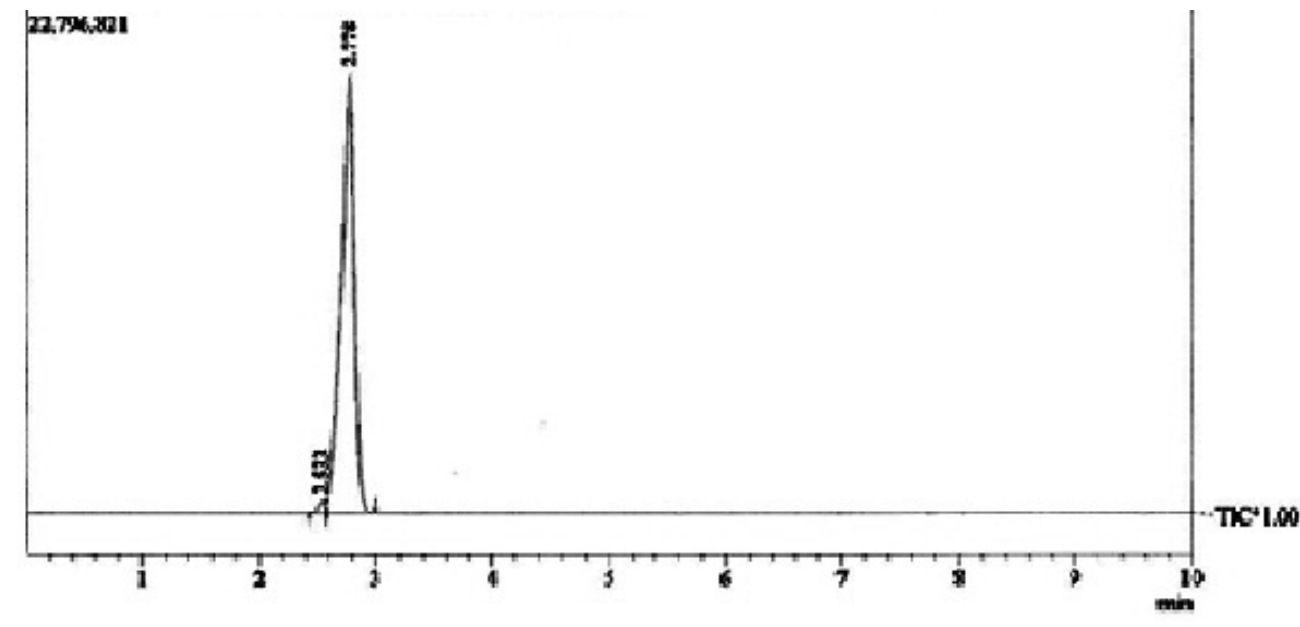

Figure 2S. Chromatogram of the agathisflavone used as standard 
Retention Time: 2.783 (Scan\#:168)

Max Peak:98 Base Peak:538.40(7179622)

Spectrum:Averaged 2.617-2.867(158-173)

Background:Averaged 0.967-2.331(59-141) Polarity:Pos Segment1 - Event1

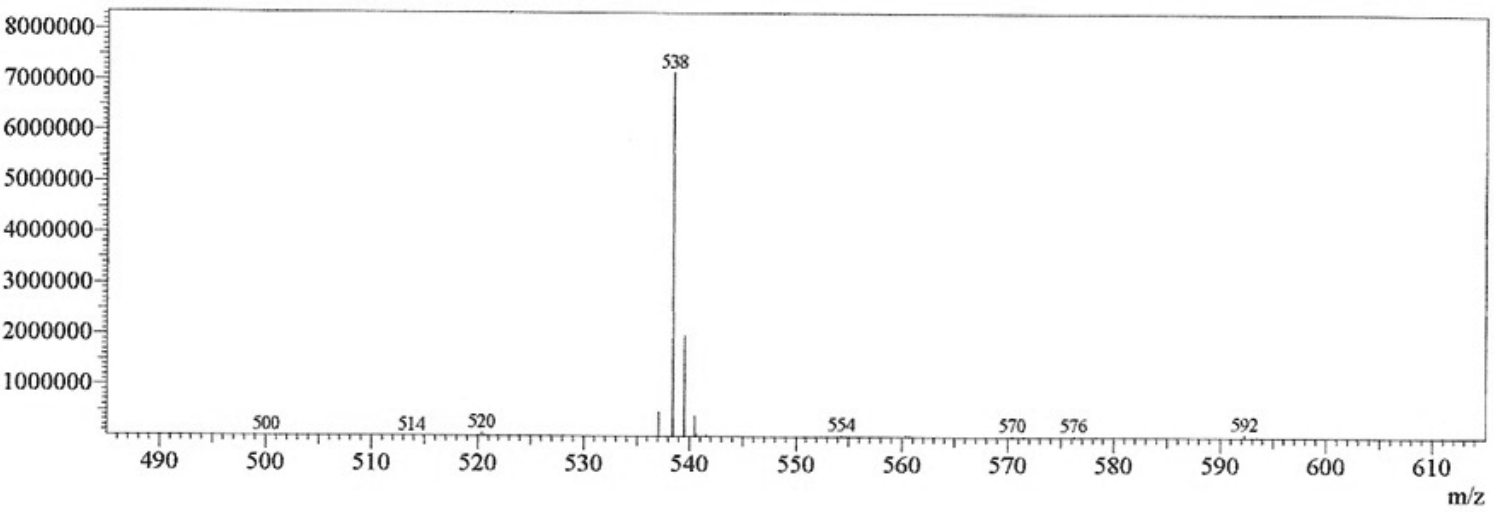

Figure 3S. APCI-Mass Spectrum of the agathisflavone standard

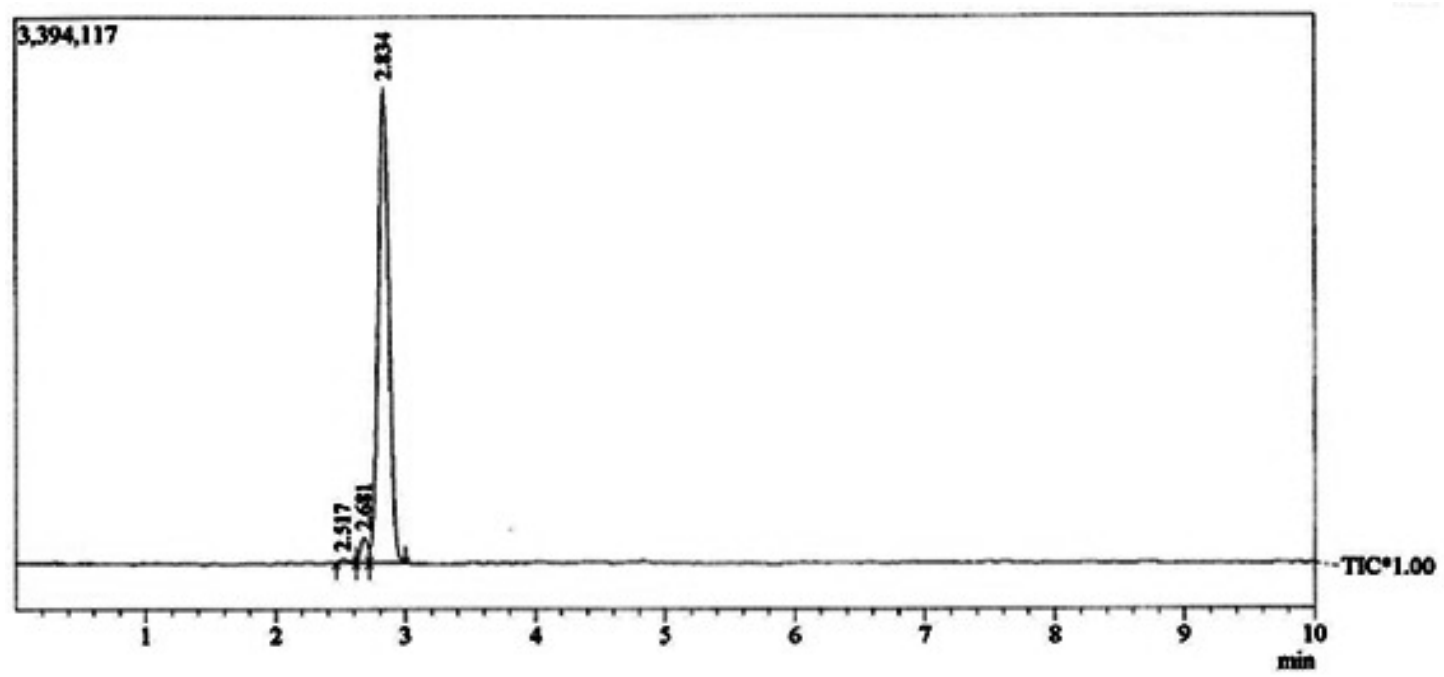

Figure 4S. Chromatogram of the amentoflavone standard

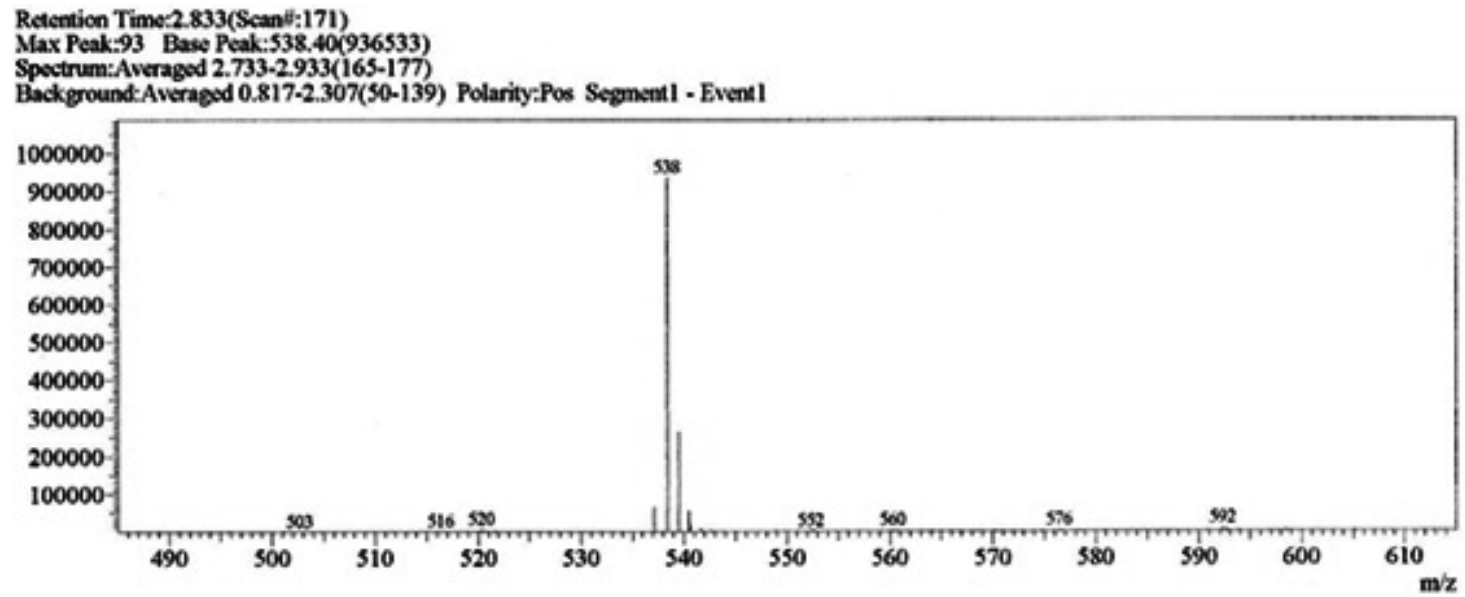

Figure 5S. APCI-Mass Spectrum of the amentoflavone standard 


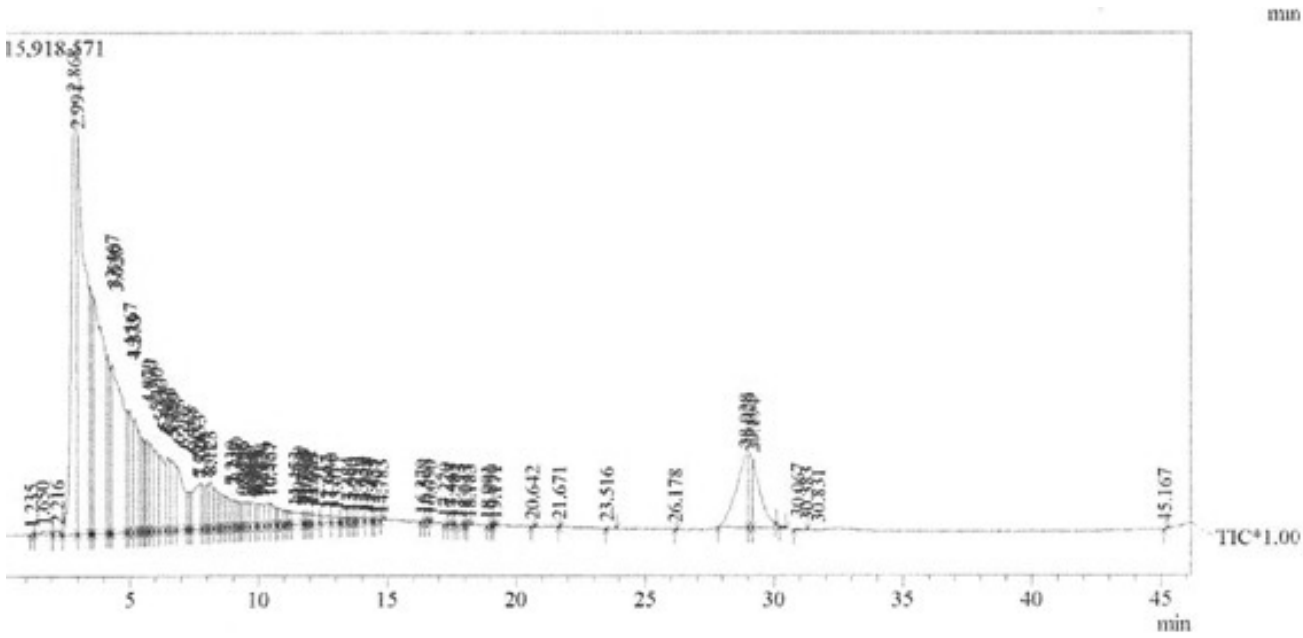

Figure 6S. HPLC chromatogram of the specimen collected at the neighborhood of Serra Talhada-PE

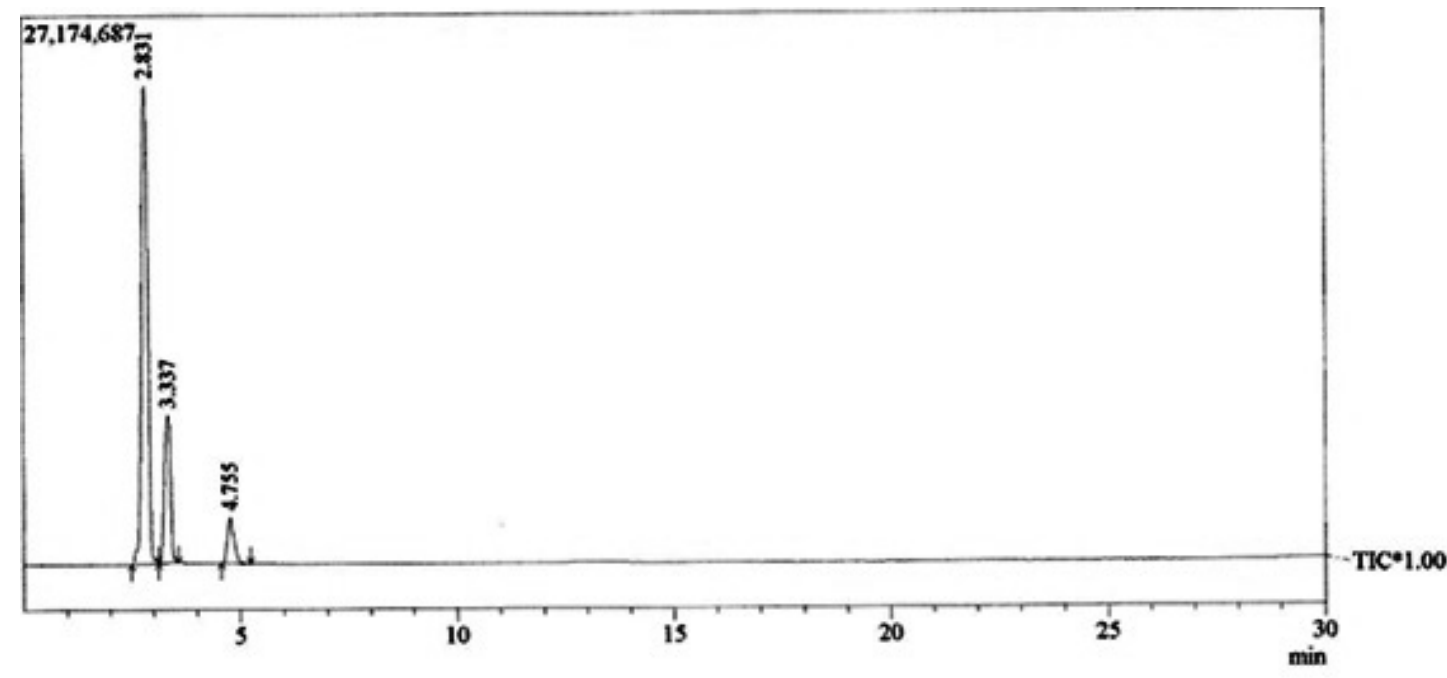

Figure 7S. HPLC chromatogram of the specimen collected at the neighborhood of Riachão do Jacuipe - BA

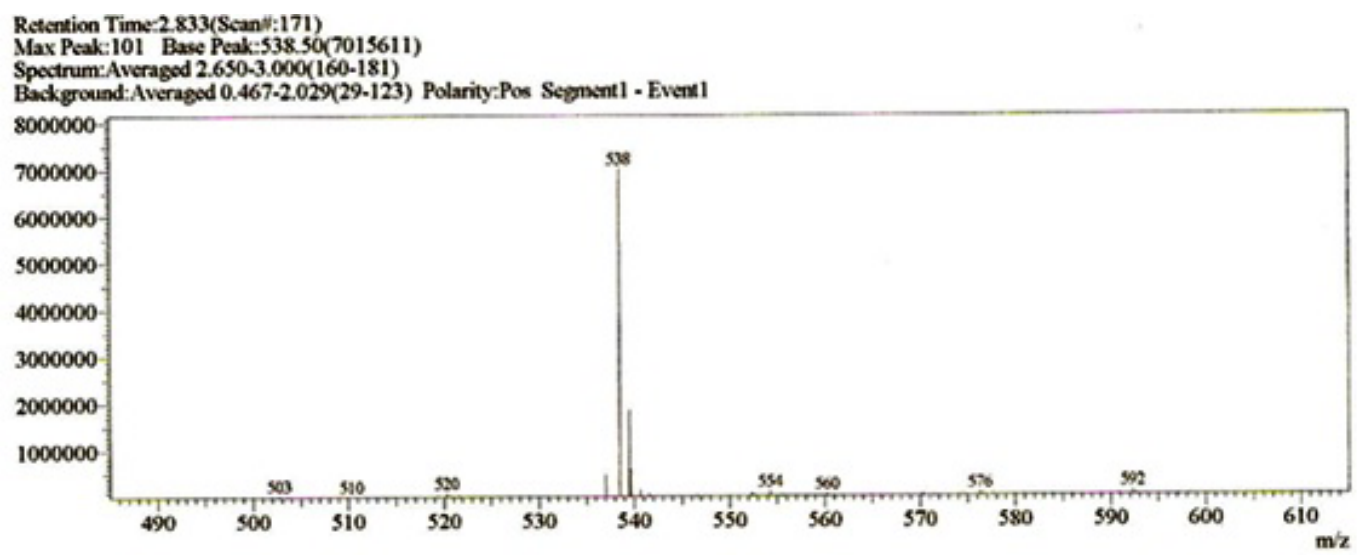

Figure 8S. APCI - Mass Spectrum of the specimen collected at neighborhood of Jacuipe - BA 


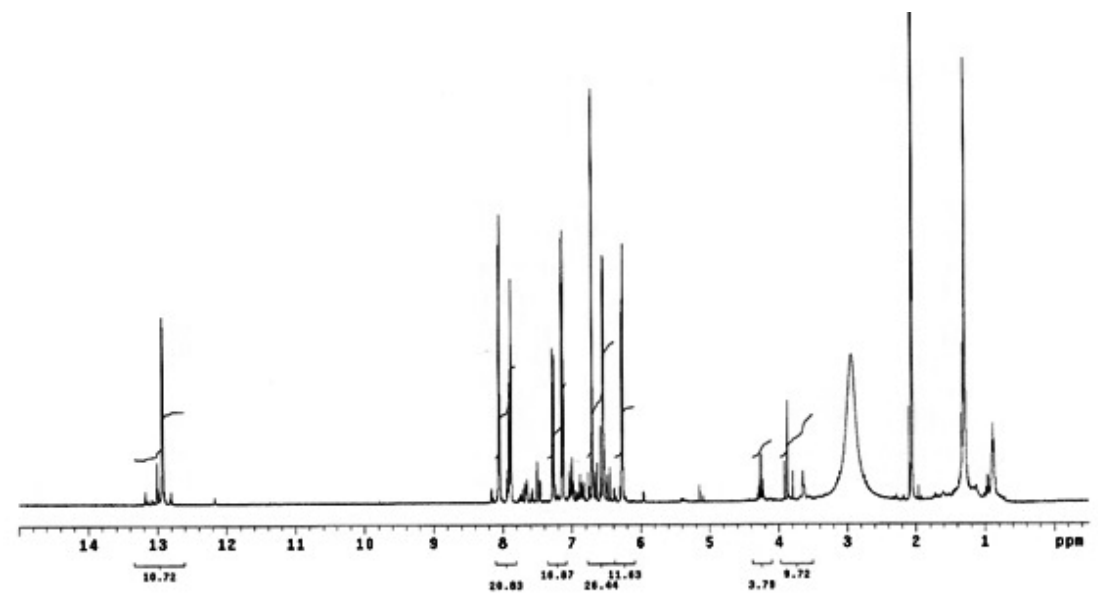

Figure 9S. ${ }^{1} \mathrm{H}$ NMR spectra of compound 1 [50O $\mathrm{MHz},\left(D_{3} C\right)_{2} \mathrm{CO}$ ]

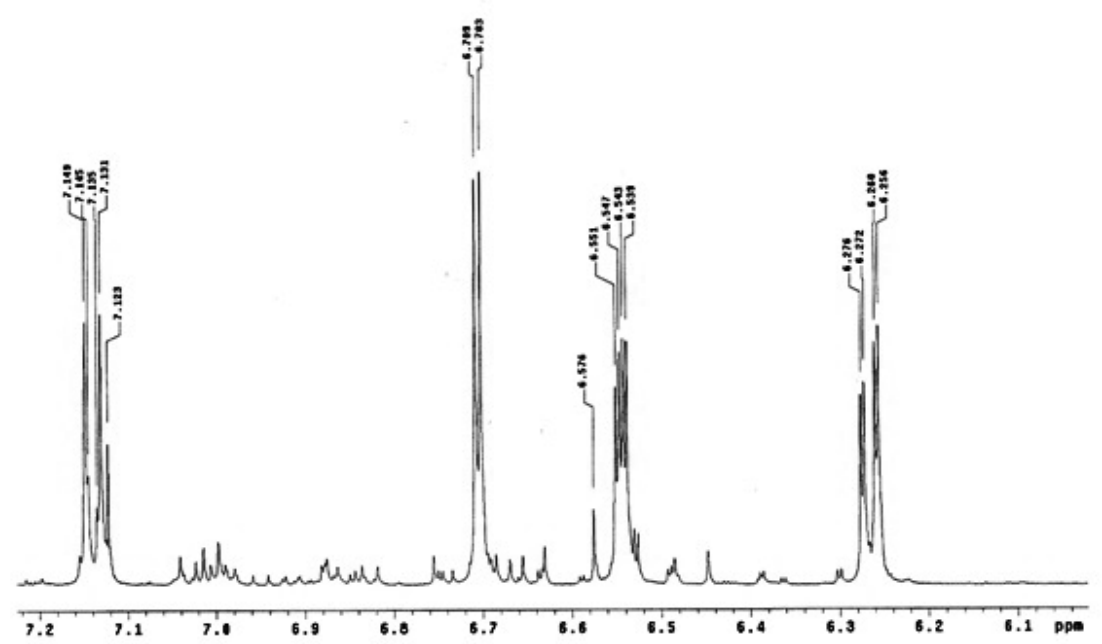

Figure 10S. Expansion of ${ }^{1} \mathrm{H} N \mathrm{NR}$ spectra of compound 1 [500 $\mathrm{MHz},\left(\mathrm{D}_{3} \mathrm{C}\right)_{2} \mathrm{CO}$ ]

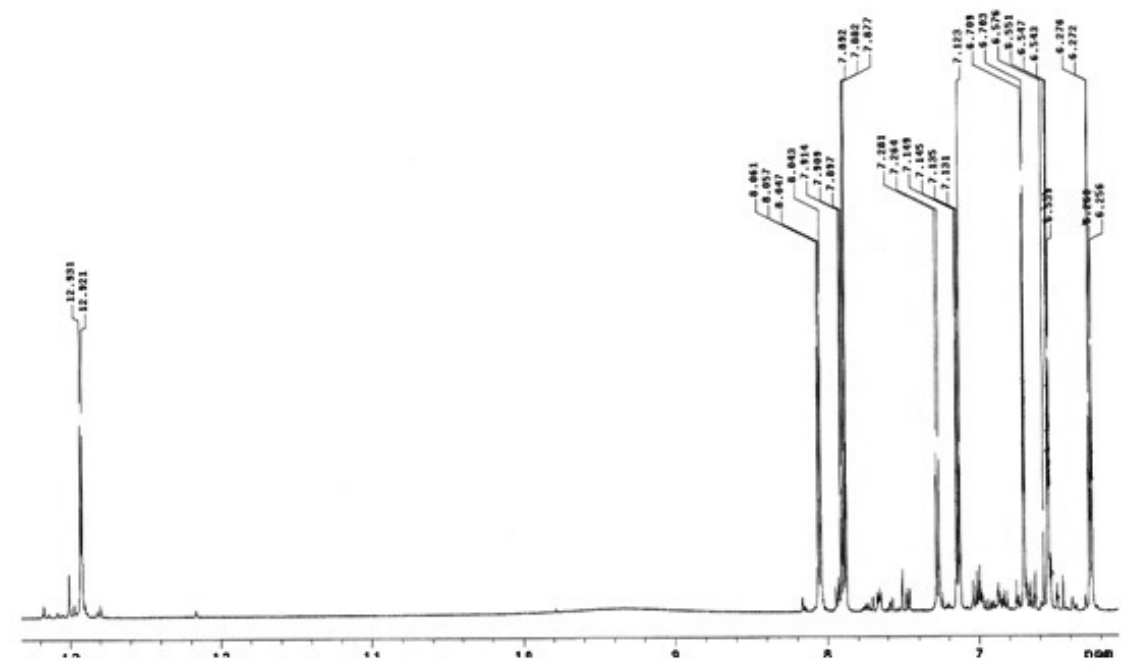

Figure 11S. Expansion of ${ }^{l} \mathrm{H}$ NMR spectra of compound 1 [500 $\mathrm{MHz},\left(\mathrm{D}_{3} \mathrm{C}\right)_{2} \mathrm{CO}$ ] 
Vol. 33, No. 6

Occurrence of biflavones in leaves of Caesalpinia pyramidalis specimens

SF

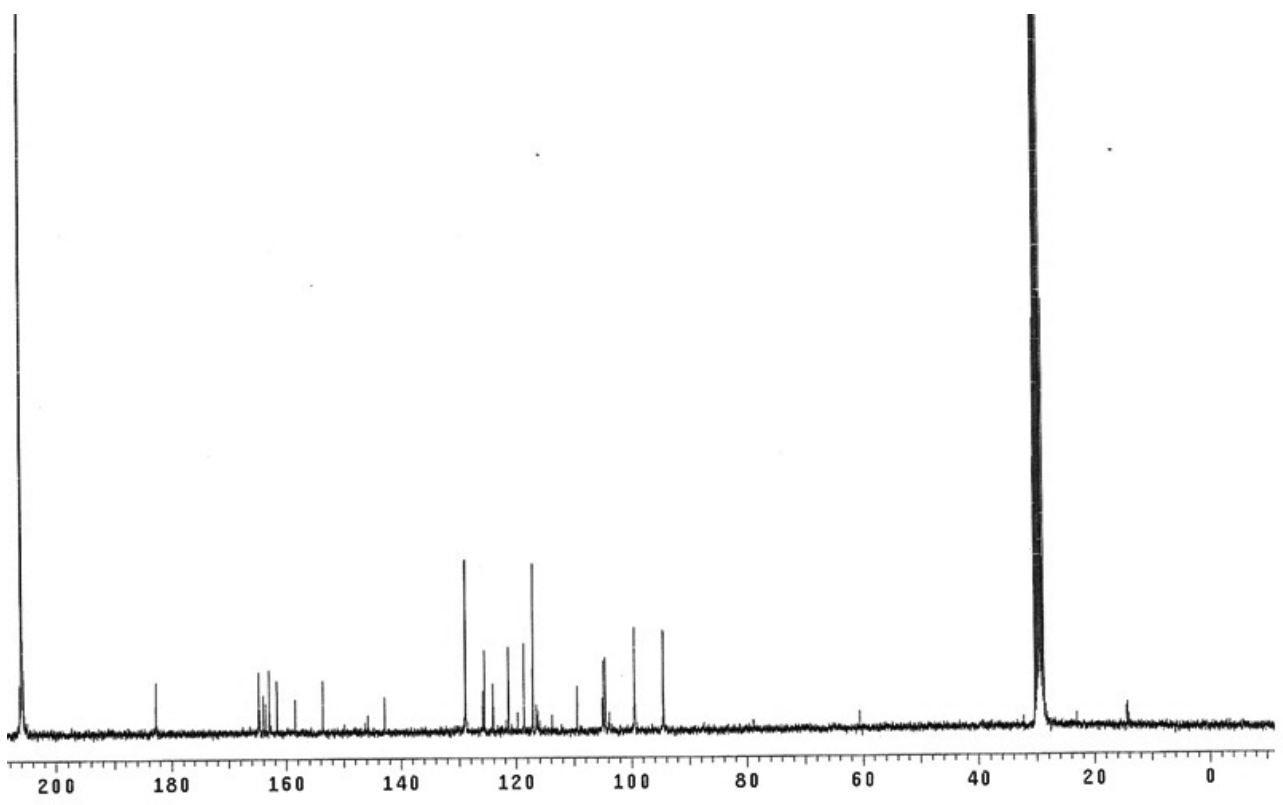

Figure 12S. ${ }^{13} \mathrm{C}$ NMR spectra of compound 1 [ $75 \mathrm{MHz},\left(\mathrm{D}_{3} \mathrm{C}\right)_{2} \mathrm{CO}$ ]

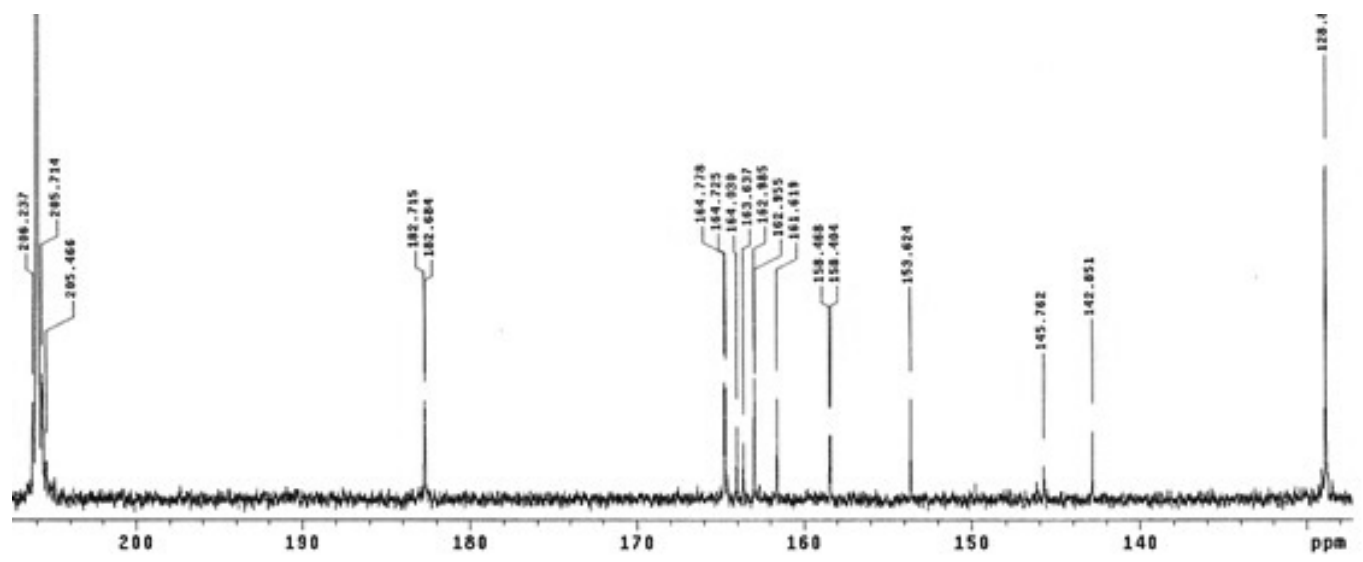

Figure 13S. Expantion of ${ }^{13} \mathrm{C} N \mathrm{NR}$ spectra of compound $1 \quad\left[75 \mathrm{MHz},\left(\mathrm{D}_{3} \mathrm{C}\right)_{2} \mathrm{CO}\right]$

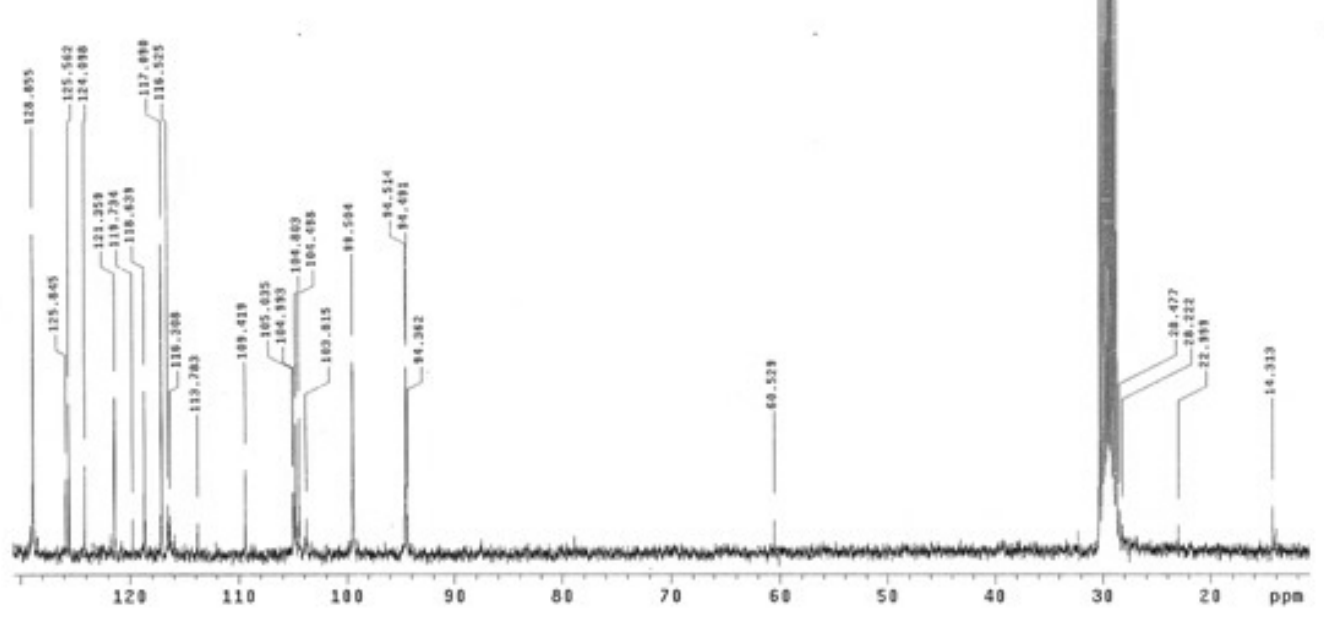

Figure 14S. Expantion of ${ }^{13} \mathrm{C} N \mathrm{NR}$ spectra of compound $1 \quad\left[75 \mathrm{MHz},\left(\mathrm{D}_{3} \mathrm{C}\right)_{2} \mathrm{CO}\right]$ 


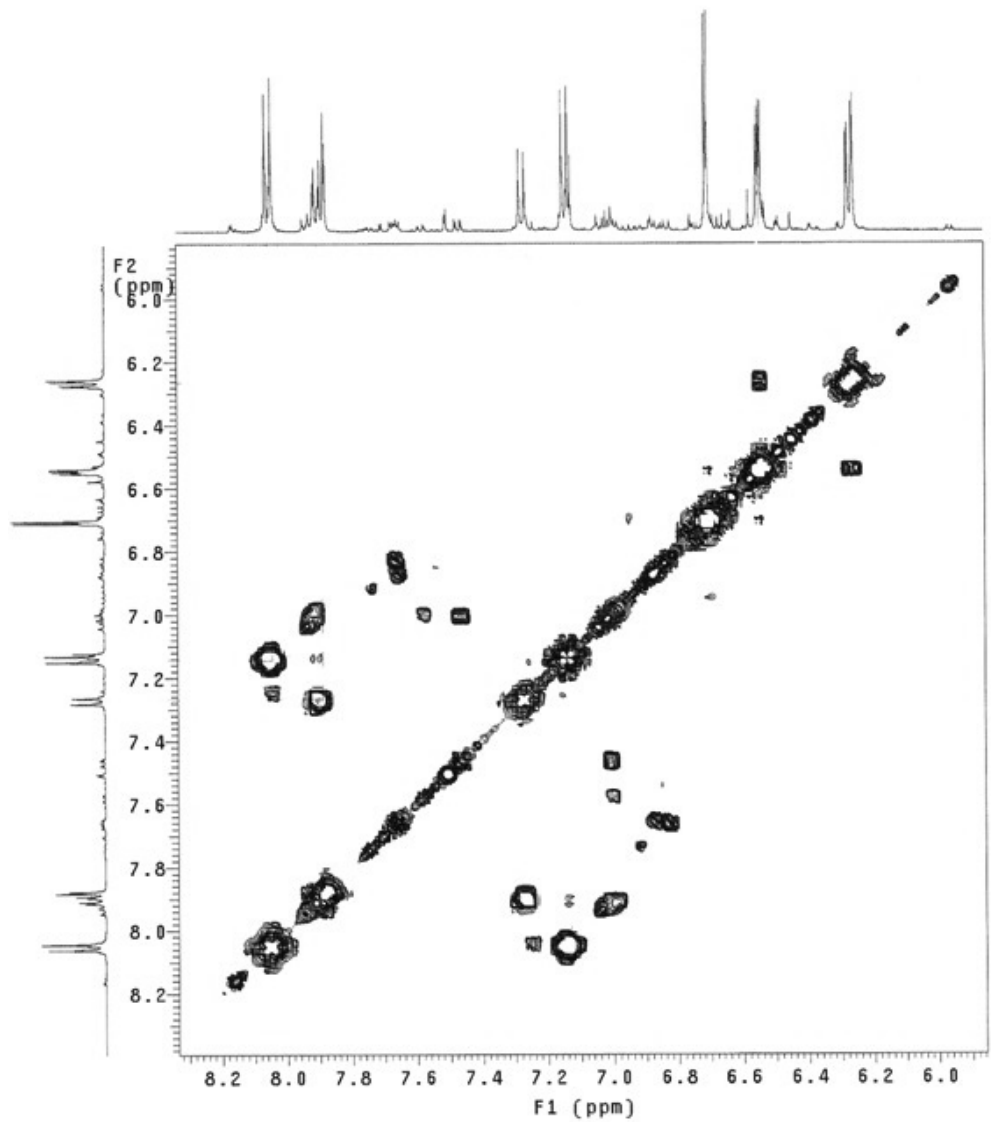

Figure 15S. $\mathrm{gCOSY}{ }^{1} \mathrm{H}-{ }^{-1} \mathrm{H}$ spectra of compound 1 [500 $\left.\mathrm{MHz},\left(\mathrm{D}_{3} \mathrm{C}\right)_{2} \mathrm{CO}\right]$

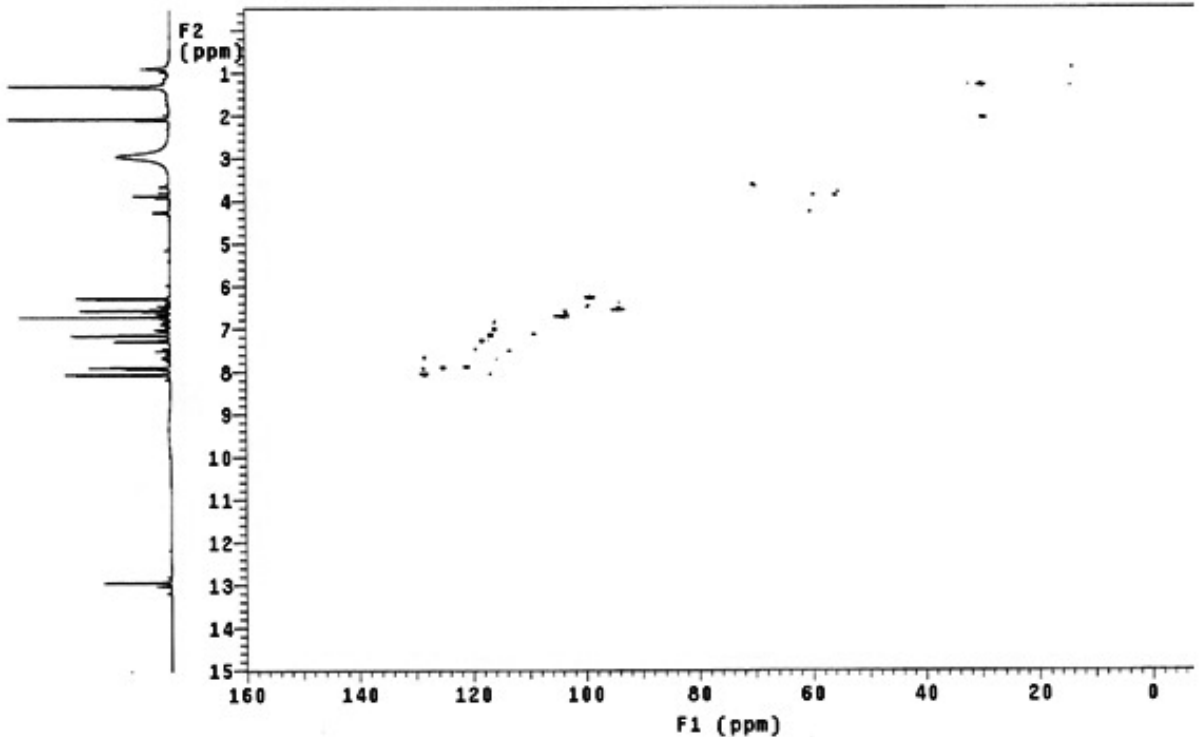

Figure 16S. HSQC spectra of compound 1 [500 $\mathrm{MHz}$ for ${ }^{1} \mathrm{H}$ and $125 \mathrm{MHz}$ for ${ }^{13} \mathrm{C},\left(\mathrm{D}_{3} \mathrm{C}\right)_{2} \mathrm{CO}$ ] 


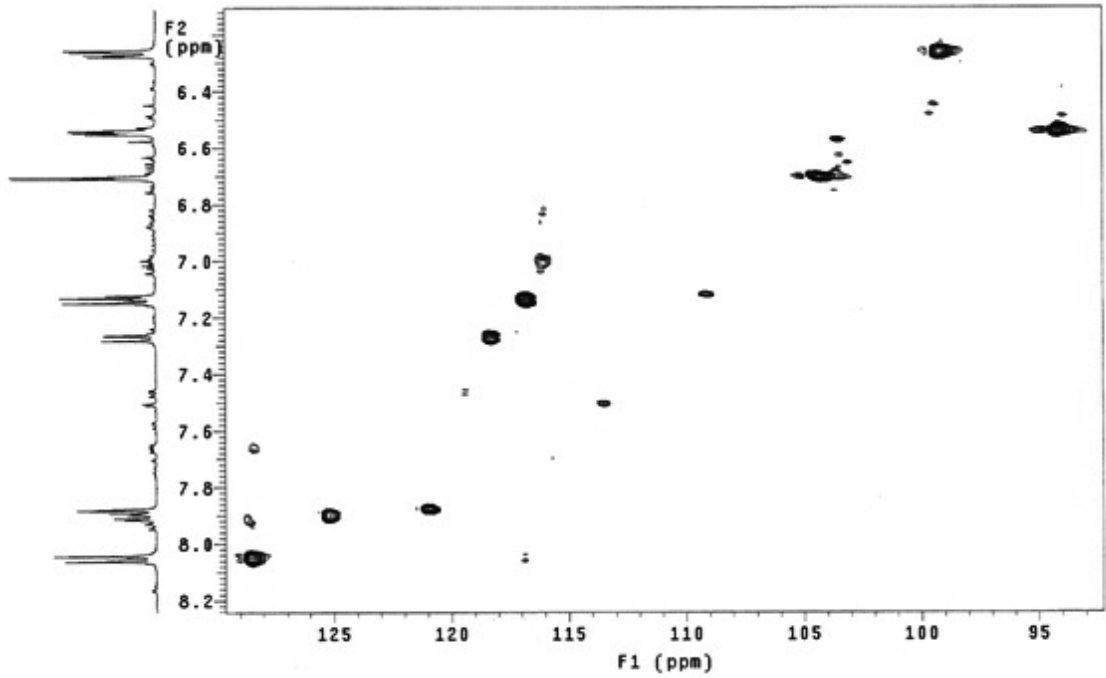

Figure 17S. Expansion of HSQC spectra of compound 1 [500 $\mathrm{MHz}$ for ${ }^{1} \mathrm{H}$ and $125 \mathrm{MHz}$ for ${ }^{13} \mathrm{C},\left(\mathrm{D}_{3} \mathrm{C}\right)_{2} \mathrm{CO}$ ]

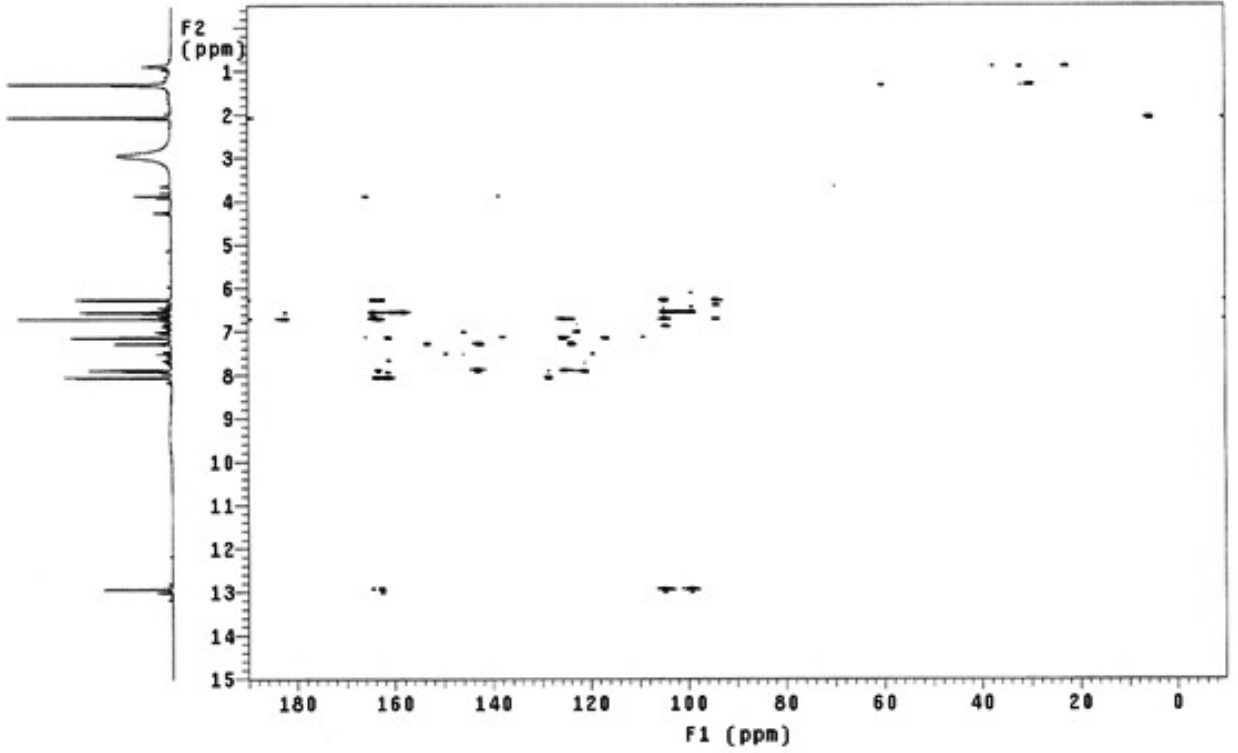

Figure 18S. HMBC spectra of compound $1\left[500 \mathrm{MHz}\right.$ for ${ }^{1} \mathrm{H}$ and $125 \mathrm{MHz}$ for ${ }^{13} \mathrm{C},\left(\mathrm{D}_{3} \mathrm{C}\right)_{2} \mathrm{CO}$ ] 


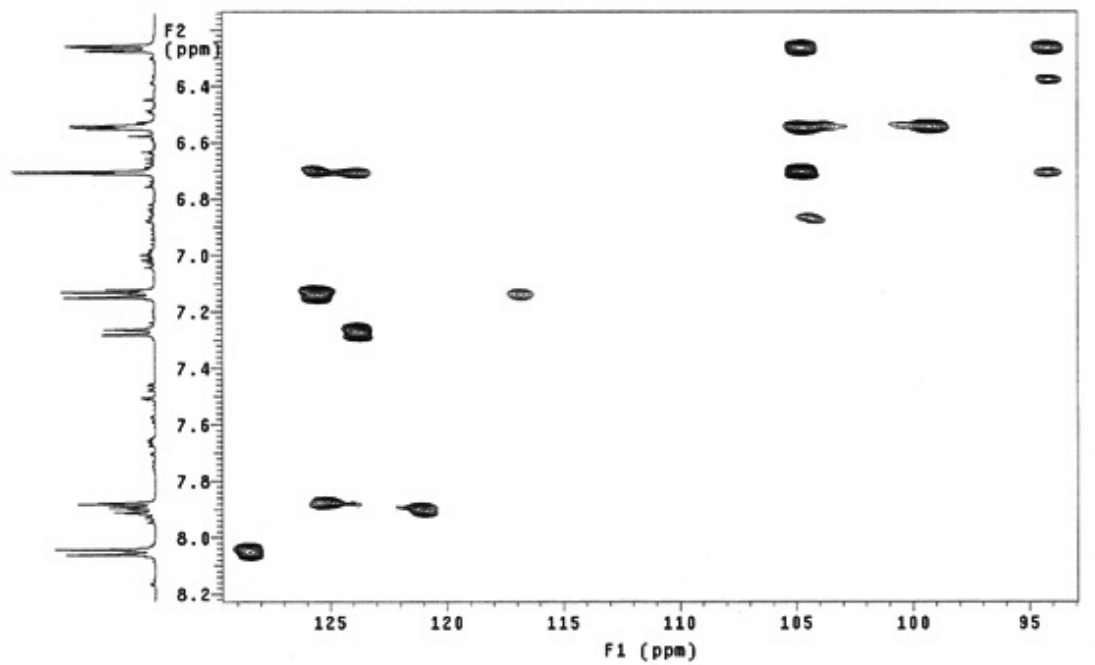

Figure 19S. Expansion of HMBC spectra of compound 1 [500 $\mathrm{MHz}$ for ${ }^{1} \mathrm{H}$ and $125 \mathrm{MHz}$ for ${ }^{13} \mathrm{C},\left(\mathrm{D}_{3} \mathrm{C}\right)_{2} \mathrm{CO}$ ]

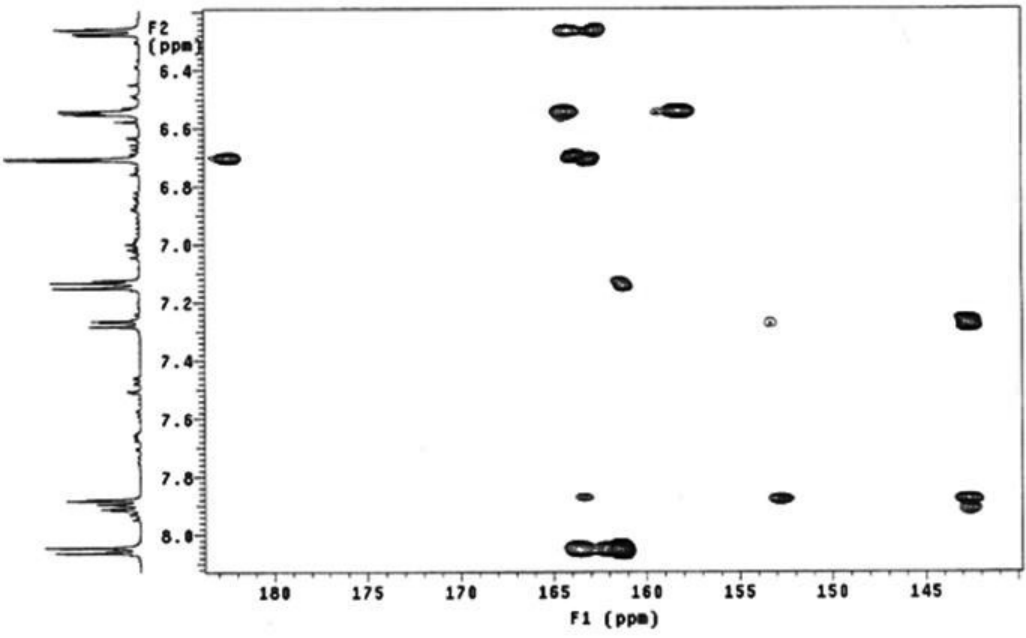

Figure 20S. Expansion of HMBC spectra of compound 1 [500 $\mathrm{MHz}$ for ${ }^{1} \mathrm{H}$ and $125 \mathrm{MHz}$ for ${ }^{13} \mathrm{C},\left(\mathrm{D}_{3} \mathrm{C}\right)_{2} \mathrm{CO}$ ]

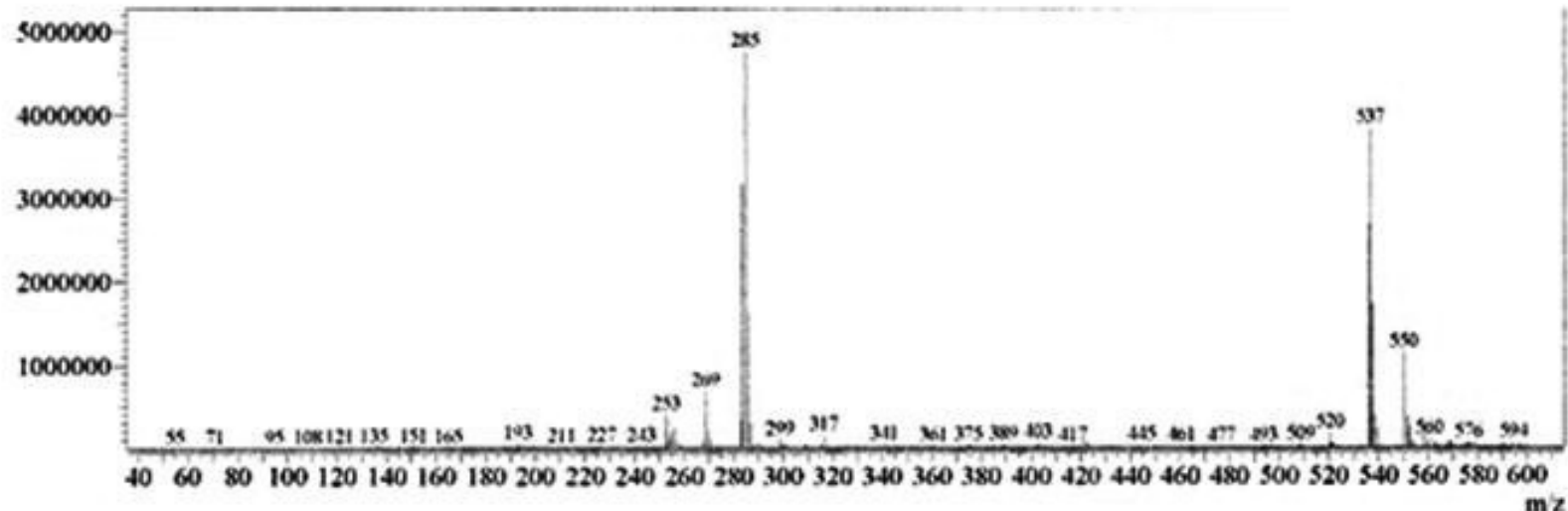

Figure 21S. Negative APCIMS of compound 1 